\title{
The Spatial Model using TRIGRS to determine Rainfall-Induced Landslides in Banjarnegara, Central Java, Indonesia
}

\author{
Agus Setyo Muntohar ${ }^{1, *}$, Gayuh Aji Prasetyaningtiyas ${ }^{2,3}$, Rokhmat Hidayat ${ }^{4}$ \\ ${ }^{1}$ Department of Civil Engineering, Universitas Muhammadiyah Yogyakarta, Yogyakarta, INDONESIA \\ Jl. Brawijaya, Tamantirto, Kasihan, Bantul, D.I. Yogyakarta. 55183 \\ ${ }^{2}$ Department of Civil Engineering, Universitas Muhammadiyah Surakarta, Surakarta, INDONESIA \\ Jl. A. Yani, Mendungan, Pabelan, Kec. Kartasura, Kabupaten Sukoharjo, Jawa Tengah 57169 \\ ${ }^{3}$ Department of Civil Engineering, Chulalongkorn University, Bangkok, THAILAND \\ 254 Phayathai Rd, Wang Mai, Pathum Wan District, Bangkok 10330 \\ ${ }^{4} \mathrm{SABO}$ Research Center, Ministry of Public Work and Housing, .D.I. Yogyakarta, Indonesia \\ JI. SABO, Sopalan, Depok, Sleman, D.I. Yogyakarta 55281 \\ ${ }^{*}$ Corresponding authors: muntohar@umy.ac.id
}

SUBMITTED 07 April 2020 REVISED 05 May 2020 ACCEPTED 10 May 2021

\begin{abstract}
Severe landslides followed by debris flow were recorded to have occurred on 12 December 2014 and discovered to have ruined infrastructures and buried hundreds of peoples in Karangkobar subdistrict of Banjarnegara district, Central Java. There was, however, a high rainfall of up to $200 \mathrm{~mm}$ per day for two days before the disaster. Therefore, this research was conducted to predict and assess the landslide area using Transient Rainfall Infiltration and Grid-Based Regional Slope-Stability (TRIGRS) version 2.0 model to calculate the pore water pressure and safety factor (FS) during rainfall infiltration. The TRIGRS model focused on spatial analysis. The data used as input for this analysis include the DEM, geological and geotechnical properties, infiltration variables, and rainfall intensity. Meanwhile, the FS value was observed to be lowest at the initial condition before rainfall infiltration by ranging between 1 and 1.2 and distributed at the steep slope area near jemblung. The results were validated through the back analysis of a reference landslide event and the instability in the area was confirmed to be initiated in the 3 three hours of rainfall while the hazards area occurs majorly at the steep slopes with slope angles greater than $30^{\circ}$ after 24 hours. The simulation results showed the steep slope area with an inclination angle greater than $30^{\circ}$ is susceptible to failure during the rainfall infiltration due to $\mathrm{FS}<1.2$ while some locations with steep slopes were likely not to fail as indicated by FS $>1.2$. This study generally concluded that the TRIGRS was able to predict the location of the failure when compared with the results from the field observation of the landslide occurrences.
\end{abstract}

KEYWORDS Landslides; Spatial; Factor of Safety; Transient; TRIGRS.

(c) The Author(s) 2021. This article is distributed under a Creative Commons Attribution-ShareAlike 4.0 International license.

\section{INTRODUCTION}

Karangkobar is a sub-district in Banjarnegara surrounded by mountainous hills and this is the reason most of the transportation infrastructures in the area are built by cutting through hills and slopes. This town experienced a landslide in more than seven locations on 12 December 2014 (Prasetyaningtiyas,2016) due to the heavy rainfall triggered by climate change which further has a severe impact on the community. Meanwhile, natural vegetation, especially grasses and scrubs, reappear almost two years after the disaster as shown in Figure 1 with some areas of the failure barely exposed. The landslides were reported to have disrupted access to Karangkobar-
Banjarnegara and buried hundreds of peoples and houses during the occurrence. Moreover, they have been classified as shallow slope failure type which was followed by debris flow and occurred due to the rainfall intensity recorded to have reached over $200 \mathrm{~mm}$ for two consecutive days in December 2014 as shown in Figure 2 . Theoretically, the intense rainfall created a temporary water table which led to an increment in the soil saturation, thereby, allowing water to fill the soil pores and caused a reduction in the soil particle bond. At this state, the pore water pressure increased while the shear strength decreased (Fredlund and Rahardjo, 1993). 


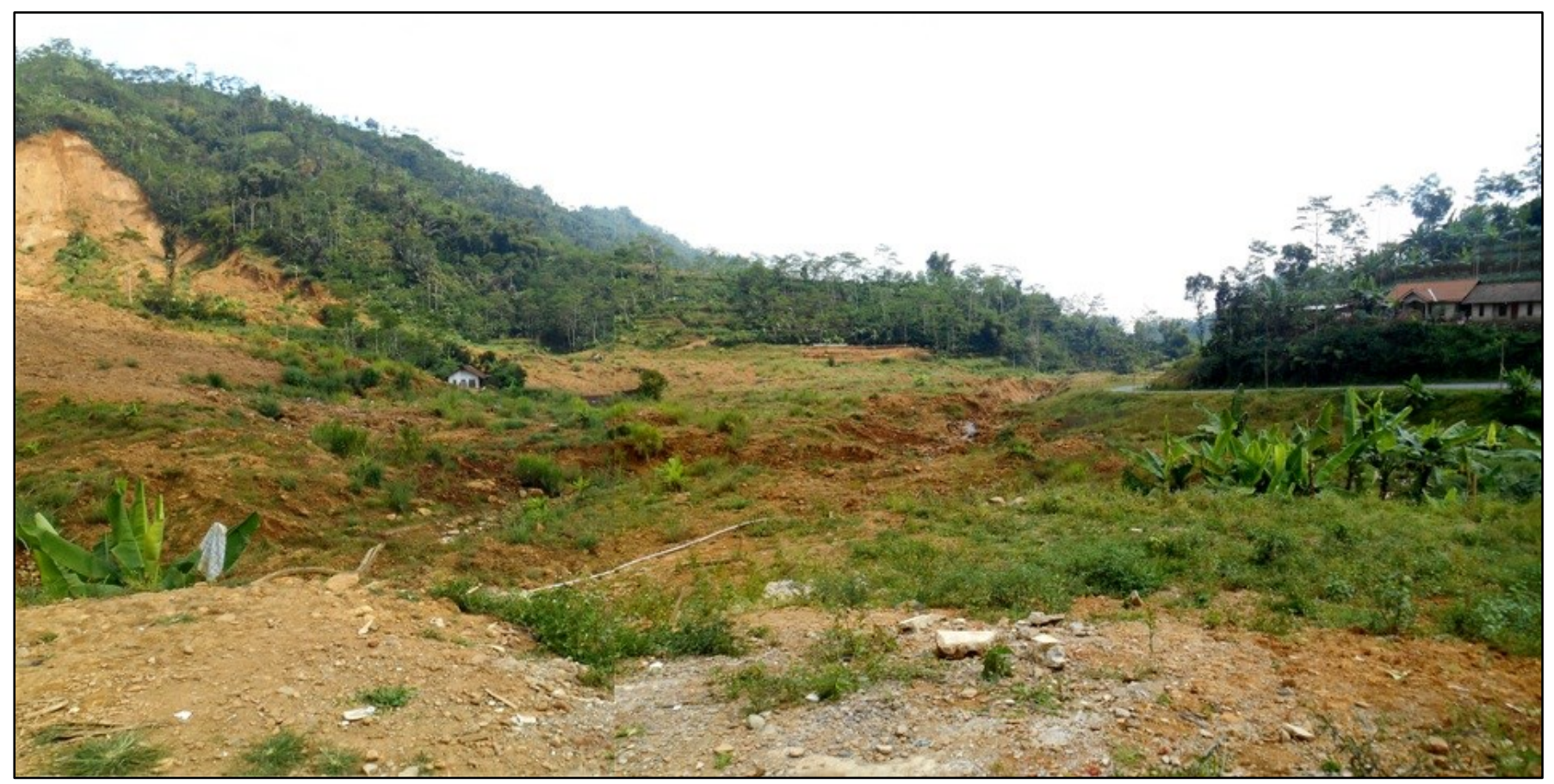

Figure 1. The condition of disaster area after April 2016

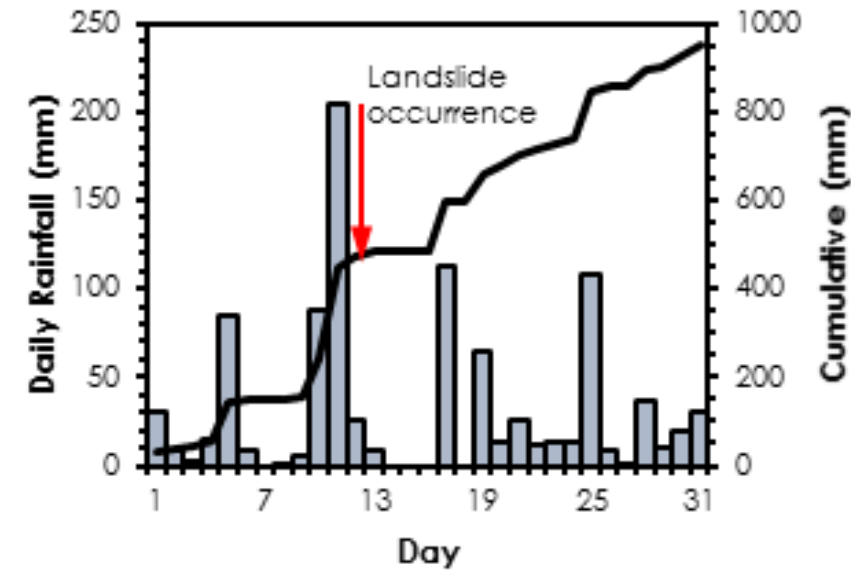

Figure 2. Precipitation records from the nearest rainfall station in Karangkobar (Prasetyaningtiyas, 2016)

Furthermore, the soil is in a slurry and unstable state when the soil is saturated. This, therefore, means the rainfall was also a triggering factor for the slope instability apart from the high inclination of the area.

Some coupled infiltration and slope stability models have been developed to model and evaluate landslides. An example of this is the TRIGRS which has been widely used to model rainfall infiltration that induces shallow landslides and debris flow (Bordoni et al., 2015, Park et al., 2013, Baum et al., 2010). It has also been applied to simulate the initial amount of landslide generated by a debris flow rather than the actual field measurement (Liu and Hsu, 2013). Moreover, Zhuang et al. (2017) and Sorbino et al. (2009) showed the ability of the model to generate more satisfactory results at a given precipitation threshold than SINMAP and SHALTAB. This means the model is ideal for landslide hazard zonation for land, infrastructural, and regional use. A comparison made also showed it is more beneficial to predict a landslide for a specific precipitation threshold, also on the regional scale. Some studies combined TRIGRS with another physical model such as DEBRIS 2D and HSP to evaluate the debris after landslides (Hsu and Liu, 2019; Ciurleo et al., 2018).

The TRIGRS model focuses on spatial analysis and this means the rainfall-induced landslide in Banjarnegara needs to be evaluated to produce a landslide hazard map based on the hydrogeotechnical approach. This research mainly focused on determining the rainfall-induced landslide and also identified the potential landslide area in Karangkobar using the spatial factor of safety. This is, therefore, for the implementation of early warning emergency plans (Chien et al., 2015) and the installation of landslide early-warning sensors (Dixon et al., 2018). 


\section{METHODS}

\subsection{Study Area and Site Characterization}

The study area is shown in Figure 3 with the landslide spots identified along the sloping road as indicated in locations 4,5 , and 6. A slope failure followed by debris flow occurred at Jemblung and the geological setting of the area is predominantly shale, marl, and calcareous sandstone as part of the Rambatan Formation (Tmr) (Condon et al., 1976). Moreover, the field observation showed the area as soft clay with a thickness of over $300 \mathrm{~mm}$. The landslide area and its surroundings are also formed by Qiya, Qjm, Qjma, andesite lava, and the volcanic clastic rocks of the volcano sliced from the Jembangan Mountains, especially andesitic, which locally contains hornblende and olivine basalt. The Qiya and Qjma are alluvium lava and sediments composed of weathered volcanic rock and a few amounts of lava and breccia flows while The Qjm and Qjo units are lava flows, breccia, pyroclastic breccias, soil, and alluvium deposits.

The boring and SPT were performed up to $24 \mathrm{~m}$ depth and the bedrock layer was found after $5-8$ $\mathrm{m}$ deep from the surface containing mainly silt and layered with fine sand. Moreover, undisturbed soil samples were collected from the site to determine the strength and hydraulic properties with the soil-water characteristics curve (SWCC) applied to determine the residual $\left(\theta_{\mathrm{r}}\right)$ and saturated $\left(\theta_{\mathrm{s}}\right)$ volumetric moisture content. These two parameters were further used as the input in the TRIGRS model. The SWCC used in this study was obtained from the suction measurement through a tensiometer in the field as indicated in Figure 4 for the soil layer. It is, however, important to note that the SWCC was fitted on the van Genuchten - Mualem model (van-Genuchten, 1980).

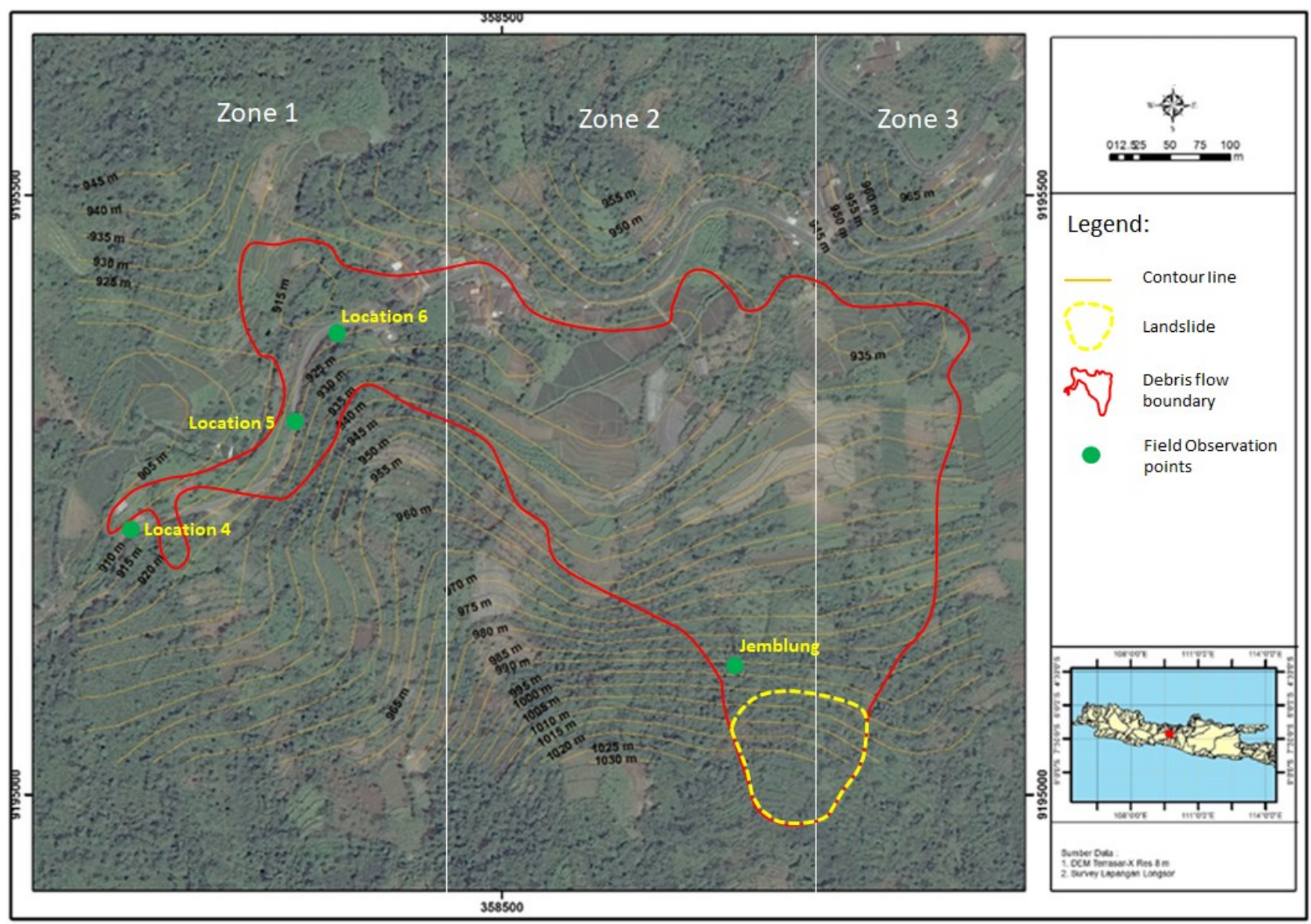

Figure 3. Topography of the investigated area. 


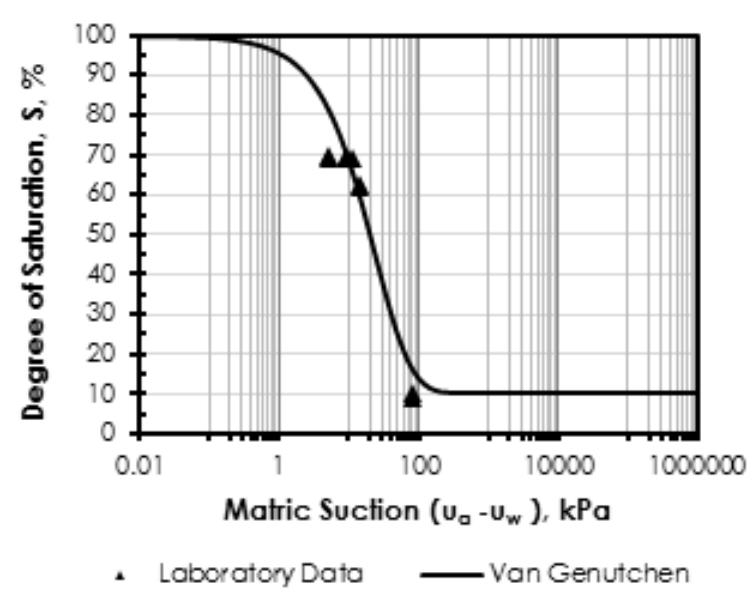

Figure 4. The SWCC of the soil layer

\subsection{TRIGRS Modelling}

TRIGRS Version 2.0 was used in this study to model the spatial slope instability and the classification of the basic input parameters includes the digital elevation model (DEM), the geotechnical, geology, and hydraulic properties of the area, and precipitation. However, the main input parameters are precipitation intensity (cri), slope angle $(\delta)$, soil depth (Z), initial ground water-table depth (depthwt), saturated vertical hydraulic conductivity $\left(\mathrm{K}_{\mathrm{s}}\right)$, hydraulic diffusivity (D), three-parameter soil-water characteristic curve, cohesion for effective stress (c), angle of internal friction for effective stress $(\phi)$, and total unit weight of soil $\left(\gamma_{s}\right)$. Figure 3 shows the boundary area and the locations using a grid to represent the area with $25 \times 25$ each cell size. In this study, the area was divided into three zones with each having different hydrological properties while the landscape digital location was transformed into ASCII text as a DEM file containing every input data. Moreover, the daily and cumulative rainfall recorded for December 2014 was collected from the rainfall station in Karangkobar with the arrow indicating the time of landslide occurrence as shown in Figure 2. The average hourly rainfall that triggered the slope failure was, however, calculated to be approximately $136 \mathrm{~mm} / \mathrm{h}\left(3.79 \times 10-5 \mathrm{~ms}^{-1}\right)$.

TRIGRS is an open file software usually executed using a bundle of an input text file which provides several lines described in the README file folder. A full description of the previous version of the software and its user manual is, however, presented in Baum et al. (2008). It is important to note that it is necessary to set all components to their initial condition for all layers before computing (Baum et al., 2010; Sorbino et al., 2009). Moreover, the simulation process uses two-layer systems for transient analysis with the bottom layer being the saturated soil under water-table while the upper layer lays on the water table and processed as unsaturated soil. The layers are, however, established to be isotropic and this makes the infiltration to be a transient and steady system. Meanwhile, Iverson's solution was applied to solve the infiltration model with the transient infiltration reported to be affecting the transient pressure head and changes in the factor of safety in the digital map (Baum et al., 2008). The steady and transient states were calculated using Equation (1) and (2) respectively (Baum et al., 2008) with some variables in each equation directly derived from experimental data while some were calculated using Equations (3) to (7).

$$
\begin{aligned}
& \psi(Z, t)=(Z-d) \beta+2 \sum_{n=1}^{N} \frac{I_{n Z}}{K_{S}}\left(H ( t - t _ { n } ) \left(D_{1}(t-\right.\right. \\
& \left.\left.\left.t_{n}\right)\right)^{\frac{1}{2}} \operatorname{ierfc}\left(\frac{Z}{2\left(D_{1}\left(t-t_{n}\right)\right)^{\frac{1}{2}}}\right)\right)- \\
& 2 \sum_{n=1}^{N} \frac{I_{n Z}}{K_{S}}\left(H ( t - t _ { n + 1 } ) \left(D_{1}(t-\right.\right. \\
& \left.\left.\left.t_{n+1}\right)\right)^{\frac{1}{2}} \operatorname{ierfc}\left(\frac{Z}{2\left(D_{1}\left(t-t_{n+1}\right)\right)^{\frac{1}{2}}}\right)\right) \\
& \psi(Z, t)=(Z-d) \beta+2 \sum_{n=1}^{N} \frac{I_{n Z}}{K_{S}} H\left(t-t_{n}\right)\left(D_{1}(t-\right. \\
& \left.\left.t_{n}\right)\right)^{\frac{1}{2}} \sum_{m=1}^{\infty}\left(\operatorname{ierfc}\left(\frac{(2 m-1) d_{L Z}+\left(d_{L Z}-Z\right)}{2\left(D_{1}\left(t-t_{n}\right)\right)^{\frac{1}{2}}}\right)+\right. \\
& \left.\operatorname{ierfc}\left(\frac{(2 m-1) d_{L Z}+\left(d_{L Z}-Z\right)}{2\left(D_{1}\left(t-t_{n}\right)\right)^{\frac{1}{2}}}\right)\right) \\
& 2 \sum_{n=1}^{N} \frac{I_{n Z}}{K_{S}} H\left(t-t_{n+1}\right)\left(D_{1}(t-\right. \\
& \left.\left.t_{n+1}\right)\right)^{\frac{1}{2}} \sum_{m=1}^{\infty}\left(\operatorname{ierfc}\left(\frac{(2 m-1) d_{L Z}+\left(d_{L Z}-Z\right)}{2\left(D_{1}\left(t-t_{n+1}\right)\right)^{\frac{1}{2}}}\right)+\right. \\
& \left.\operatorname{ierfc}\left(\frac{(2 m-1) d_{L Z}+\left(d_{L Z}-Z\right)}{2\left(D_{1}\left(t-t_{n+1}\right)\right)^{\frac{1}{2}}}\right)\right) \\
& \operatorname{ierfc}(\eta)=\frac{1}{\sqrt{\pi}} \exp \left(-\eta^{2}\right)-\eta \operatorname{erfc}(\eta) \\
& Z=z / \cos \delta \\
& \beta=\cos ^{2} \delta-\left(I_{Z L T} / K_{S}\right)
\end{aligned}
$$


$D_{1}=D_{0} / \cos ^{2} \delta$

$D_{0}=K_{S} / S_{S}$

where $d$ is the steady-state depth water table (m), $D_{0}$ is saturated hydraulic diffusivity $(\mathrm{m} / \mathrm{s}), d_{L Z}$ is the depth of impermeable boundary $(\mathrm{m}), \mathrm{I}_{\mathrm{ZLT}}$ is steady (initial) surface flux $(\mathrm{m} / \mathrm{s}), K_{s}$ is saturated hydraulic conductivity $(\mathrm{m} / \mathrm{s}), n^{\text {th }}$ is time interval infiltration, $S_{S}$ is specific storage, $t$ is time (s), $\delta$ is slope angle $\left({ }^{\circ}\right), \psi$ is groundwater pressure head (m), $z$ is positive downward (m), and $Z$ is the vertical coordinate direction $(\mathrm{m})$. The factor of safety was calculated using Equation (8). Meanwhile, the downward flow direction above the water table generates a new groundwater table and develops positive water pressure and this means the factor of safety changes with depth and time.

$F S(Z, t)=\frac{\tan \varphi^{\prime}}{\tan \delta}+\frac{c^{\prime}-\psi(Z, t) \gamma_{w} \tan \varphi^{\prime}}{\gamma_{s} Z \sin \delta \cos \delta}$

where $c^{\prime}$ is effective cohesion, $\phi^{\prime}$ is effective internal friction angle, $\gamma_{s}$ is soil unit weight, and $\gamma_{\mathrm{w}}$ is water unit weight.

\subsection{Input Parameters}

Field observation showed the variation in the geotechnical properties is almost the same for each zone. The shear strength properties were determined using a direct shear test conducted at various depths from $-3.00 \mathrm{~m}$ to $-15 \mathrm{~m}$. Moreover, the hydraulic properties of the soil represented by the saturated coefficient of permeability $\mathrm{K}_{\mathrm{s}}$ and diffusivity $\mathrm{D}_{1}$ relatively varied at each zone. The input parameters used in the simulation are, therefore, presented in Table 1.

\section{RESULTS}

\subsection{Variation of Spatial Safety Factor}

The spatial factor of safety at the initial condition before the rainfall infiltration is presented in Figure 5 with the FS values recorded to have varied from 1 to 10 . The lowest range was between 1 and 1.2 and distributed at the steep slope area near Jemblung which was theoretically initially almost stable but had the potential to slide. The focus of this study was on the change in slope stability during rainfall and the change in a safety factor is observed to be representing the slope stability at the time the rainfall stops. Figure 6 shows the minimum safety factor varies with the rainfall elapsed time and the values were simulated to be between 0.2 and 10. Meanwhile, the criteria proposed by Ward et al. (1979) divided the relative spatial hazard level into three regions and these include low when the FS $>1.7$, medium from 1.2 to 1.7 , and high at $<1.2$. The high hazard level is shown by the red color region in Figure 6 while yellow and green color areas indicate the medium and low respectively. The area with high hazard was observed to be gradually wider with the rainfall elapsed time with the unstable area discovered to have been initiated in the first three hours. Moreover, the hazard areas are majorly at the steep slope with a slope angle greater than $30^{\circ}$ after 24 hours of precipitation as indicated in Figure 7. This means the landslide area with FS < 1.2 predicted by the simulation has been confirmed by the field observation points in locations 4, 5, 6, and Jemblung as shown in Figure 7.

Table 1. Input variables used in TRIGRS for the Karangkobar landslide case

\begin{tabular}{|c|c|c|c|c|}
\hline \multirow{2}{*}{ Parameter } & & \multicolumn{3}{|c|}{ Zones } \\
\hline & & 1 & 2 & 3 \\
\hline Cohesion, $c^{\prime}$ & $\mathrm{N} / \mathrm{m}^{2}$ & $1.1 \times 10^{3}$ & $1.1 \times 10^{3}$ & $1.1 \times 10^{3}$ \\
\hline Internal friction angle, $\phi^{\prime}$ & o & 13.810 & 13.810 & 13.810 \\
\hline Saturated unit weight, $\gamma_{\mathrm{s}}$ & $\mathrm{N} / \mathrm{m}^{3}$ & $1.4 \times 10^{4}$ & $1.4 \times 10^{4}$ & $1.4 \times 10^{4}$ \\
\hline Saturated coefficient of permeability, $K_{s}$ & $\mathrm{~m} / \mathrm{s}$ & $4.0 \times 10^{-7}$ & $4.0 \times 10^{-5}$ & $4.0 \times 10^{-4}$ \\
\hline Saturated volumetric water content, $\theta_{\mathrm{s}}$ & - & 0.873 & 0.87 & 0.873 \\
\hline Residual volumetric water content, $\theta_{\mathrm{s}}$ & - & 0.09 & 0.09 & 0.09 \\
\hline SSWCC constant, $\alpha$ & - & -0.5 & -0.5 & -8.0 \\
\hline Diffusivity, $D_{1}$ & $\mathrm{~m} / \mathrm{s}$ & $6.0 \times 10^{-6}$ & $8.68 \times 10^{-4}$ & $4.12 \times 10^{-2}$ \\
\hline Rainfall intensity, $i$ & $\mathrm{~m} / \mathrm{s}$ & $3.79 \times 10^{-5}$ & $3.79 \times 10^{-5}$ & $3.79 \times 10^{-5}$ \\
\hline
\end{tabular}




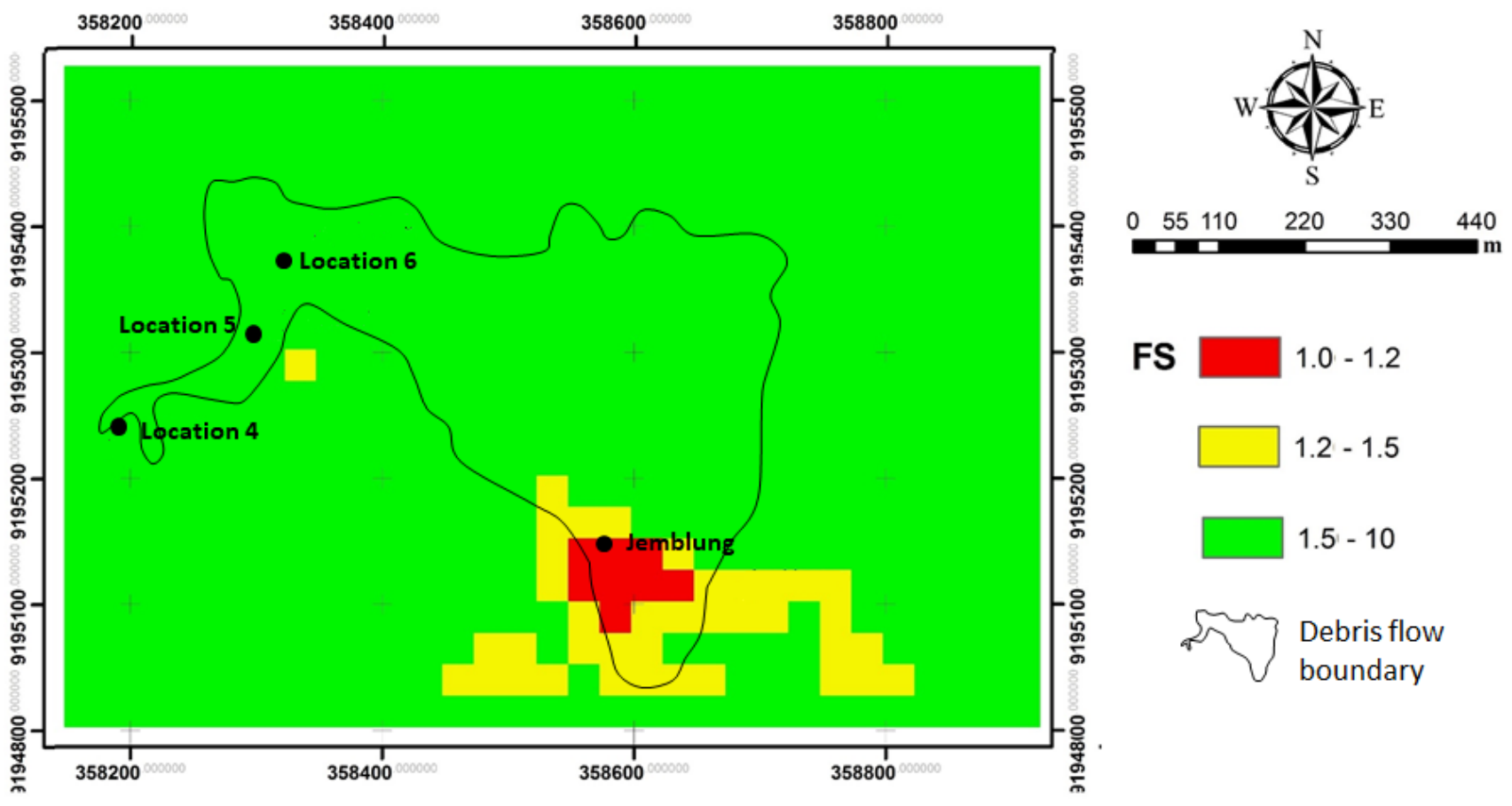

Figure 5. The initial spatial safety factor of the slope.
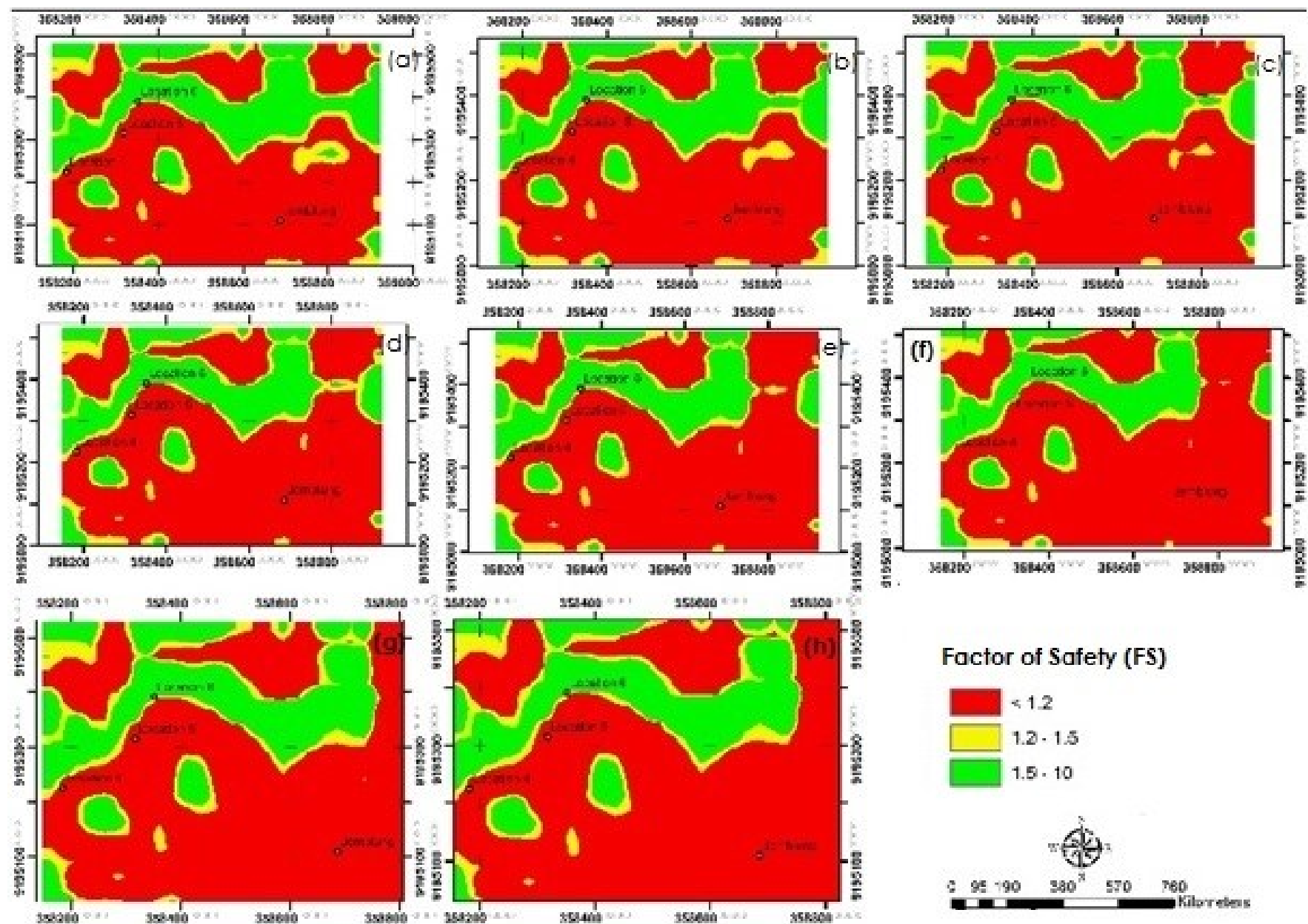

\section{Factor of Safety (FS)}

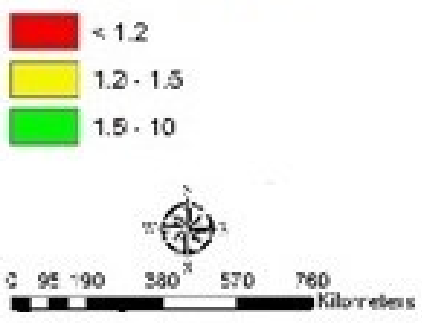

Figure 6. Slope stability conditions in terms of safety factor according to the TRIGRS model after (a) 3 hours, (b) 6 hours, (c) 9 hours, (d) 12 hours, (e) 15 hours, (f) 18 hours, (g) 21 hours, and (h) 24 hours of rainfall. 


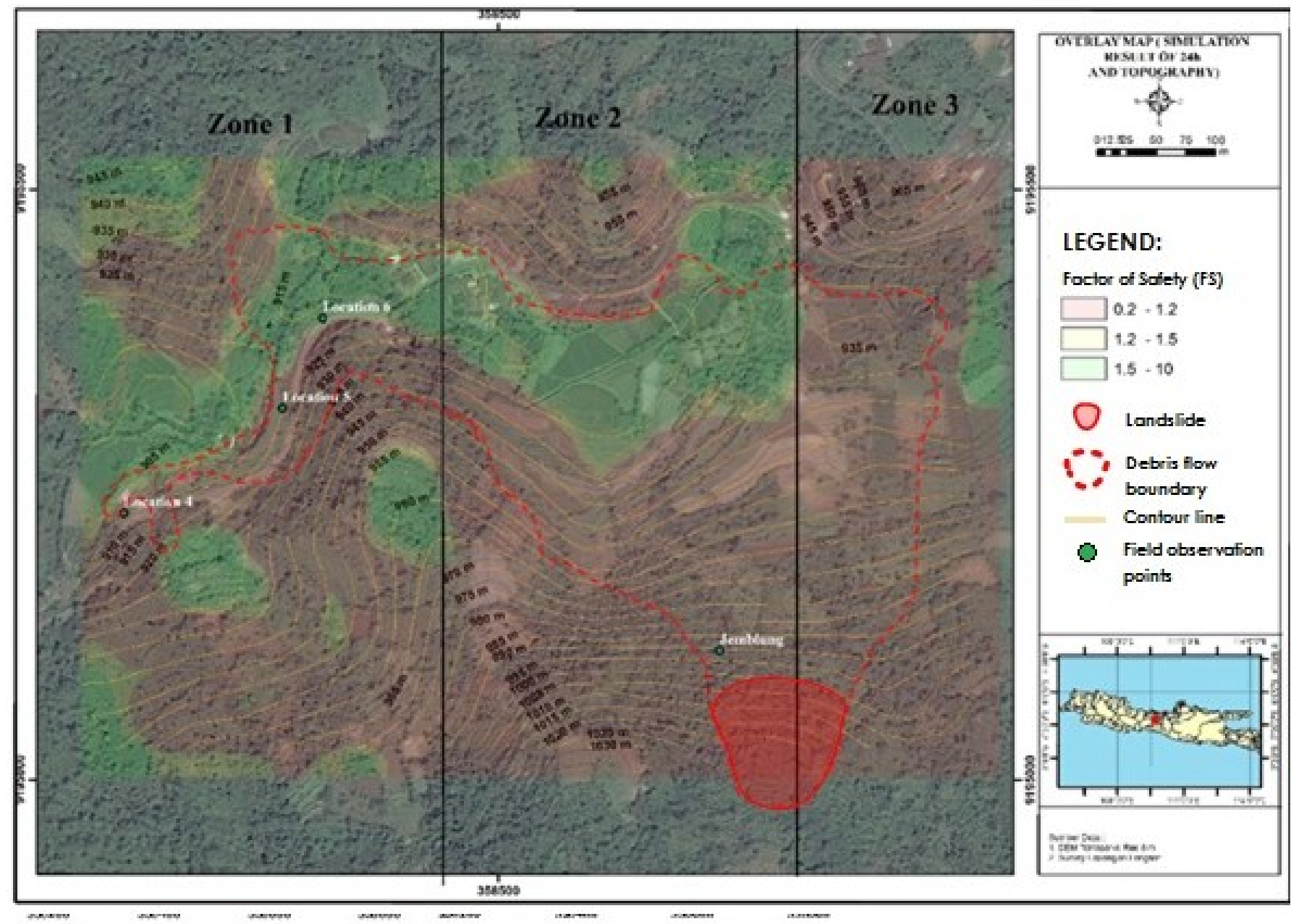

Figure 7 Predicted slope failure potential from TRIGRS simulation and observed landslides location and debris boundary.

\subsection{Variation of the Pressure Head}

Rainfall infiltration usually increases the transient pressure head and the typical change with time is presented in Figure 8.

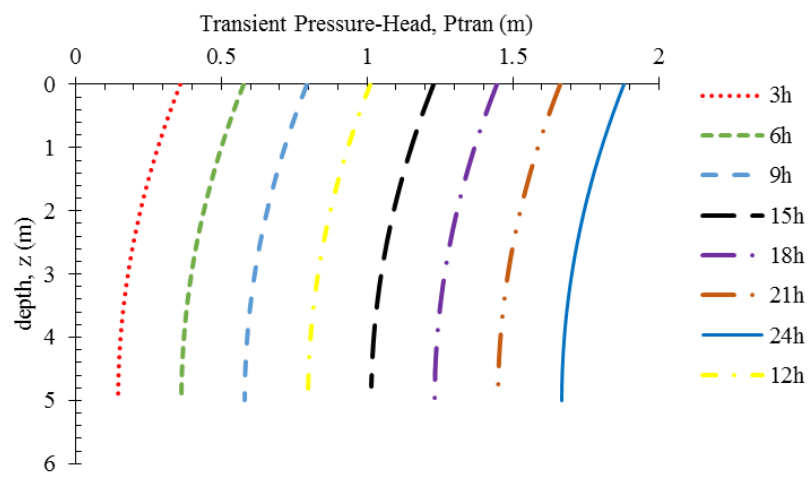

Figure 8. The variation of transient pressure head at grid cell 554.

The lowest was recorded at the location with slope angle $31^{\circ}$ which is grid cell 554 and observed to be rising gradually with the elapsed time to a significant value after 24 hours of precipitation. It increased significantly at the slope surface $(\mathrm{z}=0)$ from $0.35 \mathrm{~m}(3.43 \mathrm{kPa})$ to $1.8 \mathrm{~m}(18.64 \mathrm{kPa})$ and this positive value indicates the surface is saturated as well as the existence of run-off. Furthermore, the perched water table rises during the precipitation as indicated by the increase in the pressure head at the lower boundary of slope $(\mathrm{z}=5 \mathrm{~m})$ from $0.15 \mathrm{~m}(1.47 \mathrm{kPa})$ to $1.7 \mathrm{~m}(16.68$ $\mathrm{kPa})$.

\section{DISCUSSION}

Slope failure theoretically exists in limit state equilibrium when the safety factor value is lesser than one (FS $<1$ ) for the one or two-dimensional stability slope model. This criterion has been applied for spatial analysis by some researchers such as Baum et al. (2010), Alvioli and Baum 
(2016), Chien et al. (2015), Alvioli et al. (2014). However, Ward et al. (1979) stated that the erroneous determination of FS in spatial areas ranges from $20 \%$ to $30 \%$ and this means a high hazard area is determined when the FS $<1.2$. It further shows it is unnecessary to determine the landslide potential using FS $<1$ for the spatial analysis due to the potential errors in the variables. Therefore, it is possible to use the limits of the safety factor values for the relative hazard rankings and the probability of landslide at this condition is approximately 60 percent and more (Ward et al., 1979). Figures 6 and 7 present the predicted time and location of landslides using the TRIGRS and this is subject to the limitation from the interacting grid cell and DEM (Viet et al., 2017). Moreover, the model results are sensitive to the physical properties and hydraulic soil layers which are likely to vary and be anisotropic in the model area (Baum et al., 2008). The saturated permeability also controls the velocity of water flow and this further influences debris flow and induces slope movement based on the water flow inside the soil layer. Furthermore, diffusivity affects the water storage of soil and the soil capacity of pore water determines the maximum saturation of the soil. This is evident in the fact that when the soil moisture peaks, the soil usually becomes slurry and water routed as run-off.

Alvioli et al. (2014) showed the application of the physically-based model in predicting the time of landslides occurrence indicated the presence of both scaling properties of landslides including the intensity of the driving forces (the mean rainfall intensity and the rainfall duration responsible for the slope instabilities) and the magnitude of the consequences (the relative proportion of landslides of different sizes). This was determined by selecting reasonable values for the model parameters without changing or optimizing them to present a functional link between rainfall and landslides. Muntohar et al. (2013) also found the occurrence time of landslides to be affected by rainfall patterns and this means a well-predicted time needs a complete hourly precipitation record from the nearest rainfall measurement. Furthermore, Viet et al. (2017) showed the output of TRIGRS is very sensitive to the initial condition of the input parameter which is not easy to determine even when defined by a series of laboratory investigations. This means an assumption and field observation are possibly reliable to set the initial condition.

The landslide in this study was triggered by increasing the porewater pressure during rainfall infiltration in line with the elapsed time of precipitation. The failure mechanism was also generally found in many landslide cases to be followed by debris flow (Zhuang et al., 2017; Hsu and Liu, 2019). Moreover, the positive pressure head on the slope surface as shown in Figure 8 indicates the slope was saturated and the rainfall infiltration in each cell of the DEM was calculated in the TRIGRS from the summation of total precipitation $(P)$ and runoff in adjacent cells $\left(R_{u}\right)$. Meanwhile, runoff water flows to a lower elevation of the adjacent cell when the infiltration was greater than the capacity of saturated hydraulic conductivity $\left(K_{s}\right)$. It is also possible to combine the routing runoff flow in TRIGRS with the safety factor to estimate the debris flow area and direction as modeled by Park et al. (2013). The TRIGRS model was verified in this study through the reference landslide event in the Karangkobar area and was generally used to predict the landslide potential. Some parts predicted to be high hazard areas have not yet collapsed but soil movement is observed to be existing around the area. The model was also reported by Zhuang et al. (2017) to have been applied successfully for predictions and a comparison of its results with other models showed it is more significant to predict a landslide occurrence for a particular precipitation threshold on the regional scale. Furthermore, the differences between the predicted landslide area and field observation have been previously determined by vegetation cover and its roots in the subsurface soil layer of the study area (Saadatkhah et al., 2016). Bordoni et al. (2015) also showed the need to consider the role played by plant roots on soil reinforcement in order to develop an optimal prediction process for slope instability and agricultural management practiced in an area. 


\section{CONCLUSION}

The landslide-triggered rainfall at the mountainous area of Karangkobar sub-district, Banjarnegara district, Central Java was simulated using TRIGRS 2.0. This involved the simulation of the transient infiltration and a physical-based model of the stability conditions of natural slopes in response to rainfall events. The results were validated through the back analysis of a reference landslide event and the instability in the area was confirmed to be initiated in the 3 three hours of rainfall while the hazards area occurs majorly at the steep slopes with slope angles greater than $30^{\circ}$ after 24 hours. The safety factor in the area was simulated to have ranged from 0.20 to 1.20 with those at a higher elevation and steeper area having the lowest. The results from the TRIGRS were compared with observations made at the study site and it was discovered to have performed at an acceptable level of accuracy. However, further analysis is needed to improve the level of accuracy of the model even though it can be developed to predict rainfall-induced spatial landslides to have early warning.

\section{DISCLAIMER}

The authors declare no conflict of interest.

\section{AVAILABILITY OF DATA AND MATERIALS}

All data are available from the author.

\section{ACKNOWLEDGMENTS}

This research is a part of the "Penelitian Berbasis Kompetensi" and "Penelitian Kerjasama Luar Negeri" scheme of 2015-2020. The first author appreciates the Ministry of Research and Technology and the Ministry of Education and Culture of the Republic of Indonesia for providing the research fund. It is important to note that the Universitas Muhammadiyah Yogyakarta also supported the research through International Collaboration Research Grant Batch II/2016 and Ministry of Public Works and Housing through Landslide Disaster Crisis Center at SABO Research Center.

\section{REFERENCES}

Alvioli, M. \& Baum, R. L. 2016. Parallelization of the TRIGRS model for rainfall-induced landslides using the message passing interface. Environmental Modelling \& Software, 81, pp. 122135. doi: 10.1016/j.envsoft.2016.04.002

Alvioli, M., Guzzetti, F. \& Rossi, M. 2014. Scaling properties of rainfall induced landslides predicted by a physically based model. Geomorphology, 213, pp. 38-47. doi: 10.1016/j.geomorph.2013.12.039

Baum, R. L., Godt, J. W. \& Savage, W. Z. 2010. Estimating the timing and location of shallow rainfall-induced landslides using a model for transient, unsaturated infiltration. Journal of Geophysical Research, 115(F03013), pp. 1-26. doi: 10.1029/2009jf001321

Baum, R. L., Savage, W. Z. \& Godt, J. W. 2008. TRIGRS-A Fortran program for transient rainfall infiltration and grid-based regional slope-stability analysis, version 2.0. US Geological Survey.

Bordoni, M., Meisina, C., Valentino, R., Bittelli, M. \& Chersich, S. 2015. Site-specific to localscale shallow landslides triggering zones assessment using TRIGRS. Natural Hazards and Earth System Sciences, 15(5), pp. 1025-1050. doi: 10.5194/nhess-15-1025-2015

Chien, L.-K., Hsu, C.-F. \& Yin, L.-C. 2015. Warning Model for Shallow Landslides Induced by Extreme Rainfall. Water, 7(12), pp. 4362-4384. doi: 10.3390/w7084362

Ciurleo, M., Mandaglio, M. C., Moraci, N. \& Pitasi, A. 2018. The combined use of physically based models for the analysis of debris flow. In: Ho, K., Leung, A., Kwan, J., Koo, R. \& Law, R., eds. The Second JTC1 Workshop on Triggering and Propagation of Rapid Flow-like Landslides, 3 - 5 December 2018 Hong Kong. The Hong Kong Geotechnical Society pp. 97-100

Condon, W. H., Pardyanto, L. \& Ketner, K. B. 1976. Peta Geologi Lembar Banjarnegara dan 
Pekalongan, Jawa, skala 1:100.000., Bandung, Direktorat Geologi.

Dixon, N., Smith, A., Flint, J. A., Khanna, R., Clark, B. \& Andjelkovic, M. 2018. An acoustic emission landslide early warning system for communities in low-income and middle-income countries. Landslides, 15(8), pp. 1631-1644. doi: 10.1007/s10346-018-0977-1

Fredlund, D. G. \& Rahardjo, H. 1993. Soil Mechanics for Unsaturated Soils, New York, John Wiley \& Sons.

Hsu, Y.-C. \& Liu, K.-F. 2019. Combining TRIGRS and DEBRIS-2D Models for the Simulation of a Rainfall Infiltration Induced Shallow Landslide and Subsequent Debris Flow. Water, 11(5), pp. 890-908. doi: 10.3390/w11050890

Liu, K.-F. \& Hsu, Y.-C. 2013. TRIGRS and DEBRIS2D in Large Scale Sediment Disaster Assessment Applied in Daniao Tribe Watershed in Taiwan. International Journal of Landslide And Environment, 1(1), pp. 53-54

Muntohar, A. S., Ikhsan, J. \& Liao, H. J. 2013. Influence of Rainfall Patterns on the Instability of Slopes. Civil Engineering Dimension, 15(2), pp. 120-128. doi: 10.9744/ced.15.2.120-128

Park, D. W., Nikhil, N. V. \& Lee, S. R. 2013. Landslide and debris flow susceptibility zonation using TRIGRS for the 2011 Seoul landslide event. Natural Hazards and Earth System Sciences, 13(11), pp. 2833-2849. doi: 10.5194/nhess-13-2833-2013

Prasetyaningtiyas, G. A. 2016. Effect Soil Saturation to Slope Stability in Wanayasa Road KM. 70+350 Banjarnegara. Master Thesis, Department of Civil and Environmental Engineering, Universitas Gadjah Mada.
Saadatkhah, N., Mansor, S., Kassim, A., Lee, L. M., Saadatkhah, R. \& Sobhanmanesh, A. 2016. Regional modeling of rainfall-induced landslides using TRIGRS model by incorporating plant cover effects: case study in Hulu Kelang, Malaysia. Environmental Earth Sciences, 75(5), pp. 445-465. doi: 10.1007/s12665-016-5326-X

Sorbino, G., Sica, C. \& Cascini, L. 2009. Susceptibility analysis of shallow landslides source areas using physically based models. Natural Hazards, 53(2), pp. 313-332. doi: 10.1007/s11069-009-9431-y

Van-Genuchten, M. T. 1980. A Closed-form Equation for Predicting the Hydraulic Conductivity of Unsaturated Soils. Soil Science Society of American Journal, 44, pp. 892-898. doi: 10.2136/sssaj1980.03615995004400050002x

Viet, T. T., Lee, G., Thu, T. M. \& An, H. U. 2017. Effect of Digital Elevation Model Resolution on Shallow Landslide Modeling Using TRIGRS. Natural Hazards Review, 18(2). doi: 10.1061/(asce)nh.1527-6996.0000233

Ward, T. J., Li, R.-M. \& Simons, D. B. 1979. Mathematical modeling approach for delineating landslide hazards in watersheds. In: Humphrey, C. D., ed. The 17th Annual Engineering Geology and Soils Engineering Symposium, 4-6 April 1979 Moscow. Idaho: Division of Highway, Idaho Department of Transportation, pp. 109-142

Zhuang, J., Peng, J., Wang, G., Iqbal, J., Wang, Y., Li, W., Xu, Q. \& Zhu, X. 2017. Prediction of rainfall-induced shallow landslides in the Loess Plateau, Yan'an, China, using the TRIGRS model. Earth Surface Processes and Landforms, 42(6), pp. 915-927. doi: 10.1002/esp.4050 